Original article

\title{
Eğitimde Aile Katılımına Yönelik Akademik Çalışmaların Bibliyometrik Analizi (2000-2020)
}

\section{Bibliometric Analysis of Academic Studies on Parental Involvement in Education (2000-2020)}

\author{
Tufan İnaltekin (i) ${ }^{\text {a, }}{ }^{*}$ \& Ataman Karaçöp (i) a \\ ${ }^{a}$ Department of Science Education, Faculty of Education, Kafkas University, Kars, Turkey
}

\begin{abstract}
Özet
Aile katııımı konusundaki çalışmalar, birçok disiplin için yenidir ve bu alanın büyütülmesine ihtiyaç vardır. Bunu yapabilmenin yolu, yeni araştırmacıların ilgili literatürü anlayabilmelerinden geçmektedir. Dahası aile katılımı konusundaki çalışmaların mevcut durumunun belirlenmesi ve etkili çalışmaların hangileri olduğunun ortaya çıkarılması gerekmektedir. Bu kapsamda araştırmada, 2000-2020 yılları arasında WoS veri tabanında yer alan aile katılımı konusundaki yayınların bibliyometrik analizinin yapılması amaçlanmıştır. Veri kaynağı olarak 383 doküman ele alınmıştır. Aile katıımı konusundaki yayınların alıntı eğilimleri, yazar, kaynak, kurum ve ülkeler bakımından analiz edilmiştir. Ayrıca yayınlarda öne çıkan anahtar kelimler tematik yapısı da tanımlanmıştır. Bulgular, ilk olarak, Fan \& Chen'in (2001) dökümanının diğer çalışmları besleyen bir konumda olduğunu göstermiştir. İkinci olarak, atıf ortalamasına göre en yükek ölçüde diğer yayınlara katkıda bulunan kaynağın "Child Development” olduğu bulunmuştur. Üçüncüsü, Kanada ve Yeni Zellanda kökenli yayınların ortalama atıf sayısı bakımından diğer ülkelerden daha fazla öne çıktığı ve bu ülkelerin daha etkili yayınlar yaptığı saptanmıştır. Dördüncüsü, “California State University” kökenli aile katılımı yayınlarının ortalama atıf sayısı bakımından, diğer üniversitelere göre daha fazla öne çıktığu bulunmuştur. Beşincisi, “Kathleen V. HooverDempsey" ve "Joan M. T. Walker” isimli araştırmacıların, ortalama atıf sayısı bakımından, diğer yazarlara kıyasla öne çıktıkları görülmüştür. Son olarak "parental involvement" anahtar kelimesinin, diğer anahtar kelimelere göre yayınlarda daha fazla öne çıktığı ve en fazla bağlantı gücüne sahip kelime olduğu anlaşıımıştır. Sonuç olarak bu çalışma, akademisyenler ve uygulayıcıların aile katılımı konusunda etkili çalışmalar oluşturabilmeleri için önemli çıkarımlar sunmaktadır.
\end{abstract}

Anahtar Kelimeler: Aile katıımı, Bibliyometrik analiz, VOSviewer, Web of Science.

\section{Abstract}

Studies on parental involvement are new for many disciplines and this field needs to be expanded. The way to do this is new researchers can understand the relevant literature. Moreover, it is necessary to determine the current status of studies on parental involvement and to find out which effective studies are. In this context, it was aimed to conduct a bibliometric analysis of publications on parental involvement in the WoS database between 2000-2020. 383 documents were considered as data source. The citation trends of publications on parental involvement are analyzed in terms of author, source, institution and country. In addition, the thematic structure of the prominent keywords in the publications has also been defined. The findings first showed that Fan \& Chen's (2001) document was in a position to feed other studies. Secondly, it was found that the source that contributed

\footnotetext{
* Corresponding author:

Tufan Inaltekin is an asisstan proffesor in the depertmant of Science Education at Kafkas Üniversity in Kars, Turkey. Her research interest include the science education, Pedagocial Context Knowledge and visual representations. He lives, works and studies Kars, Turkey.

Email: inaltekintufan@gmail.com
} 
the most to other publications according to the citation average was "Child Development". Third, it has been determined that the publications originating from Canada and New Zealand stand out more than other countries in terms of average number of citations and these countries make more effective publications. Fourth, it was found that parental involvement publications from "California State University" stand out more than other universities in terms of average number of citations. Fifth, it was observed that the researchers named "Kathleen V. Hoover-Dempsey" and "Joan M. T. Walker" stood out compared to other authors in terms of average citation count. Finally, it is understood that the keyword "parental involvement" stands out more in the publications than the other key words and has the most connection power. As a result, this study offers important implications for academicians and practitioners to create effective studies on parental involvement.

Keywords: Parental involvement, Bibliometric analysis, VOSviewer, Web of Science.

Received: 25 January 2021 * Accepted: 29 January 2021 * DOI: https://doi.org/10.29329/jcre.2020.287.1

\section{GíRiş}

Eğitimde aile katılımı, okul ve aile arasındaki ortaklık olarak tanımlanmaktadır. Bu tanıma göre, hem okul hem de aile çocukların ortak eğitim hedeflerinin sorumluluğunu paylaşırlar. Dahası ailenin katılımı, bir çocuğun eğitim kariyerine yönelik ailenin veya çocuğun bakımını üstlenen kişilerin, yaptıkları yatırımları içerir. Ailelerin, çocuklarının okul içi ve dışındaki doğrudan öğrenme etkinliklerinde ve diğer faaliyetlerinde yer almaları eğitimde aile katılımı olarak tanımlanır (LaRocque, Kleiman \& Darling, 2011; Levin \& Sutherland, 2013). Günümüzde birçok aile, çocuklarına okulda veya evde yardımcı olmak için farklı türdeki öğrenme etkinliklerine gönüllü olarak katılırlar. Çocukların yaşları, sınıf düzeyleri, başarı düzeyleri, ırk, okul ilişkileri, kaynaklar, öğrenme güçlüklerinin olması, aile ve çevre koşullarındaki farklılıklar, onların eğitim yaşantısına aile katılımının ne düzeyde olması gerektiğini etkilemektedir (Malone, 2015; Washington, 2016).

Aileler, çocuklarının eğitimsel gelişimini beslemede dinamik role sahiptirler (Gross, Bettencourt ve Taylor, 2020). Her aile, gelir düzeyi, etnik ve kültürel geçmişine bakılmaksızın bir öğrenme ortamı işlevi görür. Ailelerin, eğitim etkinlikleri ve deneyimler düzenleyerek çocuklarına gerekli becerileri öğretmeleri gerekmektedir. Piaget'in sosyal gelişim teorisi, aile katılımının çocukların gelişimi ve başarısında önemli bir faktör olduğu fikrini desteklemektedir (Al-Mahdi, 2019; Epstein, 2010; Tekin, 2011). Ayrıca, Vygotsky'nin sosyo-kültürel teorisi, öğrenme sürecini, bireyin aktif olarak daha geniş sosyal uygulamalar döngüsüne katıldığında gerçekleşen bir eylem olarak açılar. Bu aktif katılıma; aileler, akranlar veya öğretmenler gibi başkalarıyla olan sosyal etkileşimleri içermektedir. Çocukların ilk öğretmenleri aileleri olduğundan ve ilk öğrenmeleri bu yapı içerisinde gerçekleştiğinden dolayı aile üyeleri ile etkileşimleri onların gelişmeleri için çok önemlidir. Bu sosyal etki, bireylerin diğer bireylerle veya gruplarla etkileşimi sonucunda düşüncelerini, duygularını veya davranışlarını değiştirmeleri olarak tanımlanmıştır (Cook-Craig, 2010; Wanat, 2010). 
Ailede öğrenmeye ve bilime karşı tutum ve davranışlar, çocukların hayatlarındaki öğrenme isteklerini şekillendirmede önemli rol oynamaktadır (Nugent vd., 2015; Rice vd., 2013). Özelliklede erken yaşlarda çocukların öğrenme yaşamları ve kariyer seçimlerinde aileler, en önemli motivasyon kaynağı olarak görülmektedir. Dahası ailelerin çocuklarının erken yaşlardaki bilim yolculuklarına yapacakları doğru rehberlik ve destek, onların akademik gelişimlerine ciddi katkılar sağladığını göstermektedir (Cridge \& Cridge, 2015; Halim, Rahman, Zamri \& Mohtar, 2018; Sawitri, Creed \& Zimmer-Gembeck, 2014).

Epstein (2001) aileler ve onların sahip olduğu kültürün, çocukların eğitim anlayışında oynadığı role dikkat çekilmektedir. Bugün küreselleşme ve göç döneminde olan dünyada tüm etnik ve farklı ekonomik yapılardan gelen ailelerin, çocuklarının eğitim süreçlerindeki dezavantajlı durumları, azaltmak için bilinçli bir şekilde aktif rol almaları gerektiğine vurgu yapılmaktadır (Silander vd., 2018; Windle, 2015).

İlgili literatür ev ortamının ve kaynaklarının öğrencilerin akademik hayatında önemli bir rol oynadığına dikkat çekmektedirler (Geesa, Izci, Song ve Chen, 2019; Stables vd., 2018). Yine araştırmalar, öğrencilerin akademik başarısını etkileyecek motivasyonel iklim için ailenin en önemli değişken olduğuna dikkat çekmektedir (Owen vd. 2014; Schulze ve Lemmer, 2016; Schulze ve Lemmer, 2017). Bunu destekletyen bir araştırmada, Xu vd. (2018) ailelerin çocuklarının ödevlerine yardımcı olma konusunda tam adapte oldukları yaklaşımlarda, yani soru sorarak onları teşvik etmlerinin, düşüncelerini ya da ödev planlarını dinlemelerinin onların akademik başarısını artırdığını göstermişlerdir. $\mathrm{Bu}$ bağlamda çocuğun eğitiminde ailenin nitelikli katılımının, akademik başarıyı getiren anahatar faktör olarak karşımızda durduğunu söyleyebiliriz.

\section{Araştırmanın amacı ve soruları}

Aile katılımının, çocuğun eğitimindeki önemi düşünüldüğünde bu konudaki araştırmaların daha iyi anlaşılmasının ve zenginleştirlmesinin gerekli olduğu görülmektedir. Dahası bu alanı büyütmek için araştırmacıların ilgili literarü iyi tanıyabilmesi ve buna dayalı okumalar yapabilmeleri gerekmektedir. Aile katılımı konusunda daha nitelikli yayınların üretilmesi ve eksik parçaların tamamlanabilmesi, alanda etkili olan çalışmaların irdelenmesiyle mümkündür. Bu amaca hizmet etmek için, çalışmada, son yirmi yılda (2000-2020) eğitimde aile katılımı üzerine yayımlanan akademik çalışmaların bibliyometrik analizinin yapılması amaçlanmıştır. Bu kapsamda cevabı aranan sorular şunlardır:

1. Eğitimde aile katılımı üzerine yapılan araştırmalarda en çok atıf alan yazarlar kimlerdir?

2. Eğitimde aile katılımı üzerine yapılan araştırmalarda en çok atıf alan dökümanlar hangileridir?

3. Eğitimde aile katılımı üzerine yapılan araştırmalarda en çok atıf yapılan dergiler hangileridir?

4. Eğitimde aile katılımı üzerine yapılan araştırmalarda en çok atıf alan kurumlar hangileridir?

5. Eğitimde aile katılımı üzerine yapılan araştırmalarda en çok atıf alan ülkeler hangileridir? 
6. Eğitimde aile katılımına ilişkin yayınların atıf sayılarının dokümanlar, kaynaklar, yazarlar, kurumlar ve ülkelere göre ağ haritası nasıldır?

7. Eğitimde aile katılımı üzerine araştırmalarda en çok kullanılan anahtar kelimeler hangileridir? Ve bu çalışmaların anahtar kelimeler ağ haritası nasıldır?

\section{YÖNTEM}

\section{Araştırmanın Tasarımı}

$\mathrm{Bu}$ araştırmada, eğitimde aile katılımı konusundaki yayınların durumunu keşfetmek için bibliyometrik analiz yaklaşımı kullanılmıştır. Bibliyometrik analiz, bir araştırma alanının genel görünümü ve önde gelen araştırmacıların analizini ortaya koymak için yapılmaktadır (Bjork, Offer \& Söderberg, 2014). Dahası bibliyometrik analiz, belirli bir araştırma alanıyla ilgili literatürü haritalandırmak için yararlı bir araçtır (Falagas, Karavasiou \& Bliziotis, 2006). Bibliyometrik analiz, bir araştırma konusunun evrimini incelemek ve belirli bir araştırma alanındaki yayınların göreceli önemini değerlendirmek için kullanır (Gimenez \& Prado-Gasco, 2019). Bibliyometrik analizin sonuçları, belirli bir araştırma alanında ilerlemeye birçok farklı yoldan katkıda bulunur. Özellikle, ilgili araştırıma alanında kaydedilen ilerlemenin değerlendirilmesine izin verir, en güvenilir ve popüler bilimsel yayın kaynakları tanıtır (Geng vd., 2017). Ayrıca, araştırmacıların potansiyel araştırma konularını belirlemelerine, ortak çalışma yapacakları uygun araştırma kurumlarını tanımalarına ve potansiyel akademik işbirlikçileri belirlemelerine yardımcı olur (Martínez, Cobo, Herrera \& Herrera-Viedma, 2015).

\section{Veri kaynakları}

Bu çalışmada, 18 Ocak 2021 tarihinde, WoS veritabanında anahtar kelime olarak "Parental Involvement" ifadesi arandı ve bu kapsamda 383 akademik çalışmaya ulaşıldı. Bu çalışmların, ayrıntılı parametreleri Grafik 1'de gösterilmiştir. 
Tablo 1. Araştırmaya dahil edilen yayınların tipi ve dil yapısı dă̆ı̆ımı

\begin{tabular}{llll}
\hline Kategori & & $\mathrm{f}$ & $\%$ \\
\hline & Hırvatça & 1 &, 3 \\
& Flemenkçe & 1 &, 3 \\
İngilizce & 366 & 95,6 \\
Yayın Dili & Fransızca & 2 &, 5 \\
& Almanca & 3 &, 8 \\
& Rusça & 1 &, 3 \\
& İspanyolca & 7 & 1,8 \\
& Türkçe & 2 &, 5 \\
\hline & Makale & 344 & 89,8 \\
Yayın Türüi & Kitap & 1 &, 3 \\
& Kitap Bölümü & 33 & 8,6 \\
& Konferans Bildirisi & 5 & 1,3 \\
\hline
\end{tabular}

Kaynak: Web of Science Core Collection (18.01.2021)

Tablo 1'de bu araştırmada kullanılan dökümanların türü ve dil yapısı gösterilmektedir. WoS üzerinden elde edilen 383 çalışmanın türü incelendiğinde \%89.8'i (n=344) makale, \%8.6'sı (n=33) kitap bölümü, \%1.3’ü $(n=5)$ konferans bildirisi ve \%0.3'ünün $(n=1)$ ise kitaptan oluştuğu görülmektedir. Ayrıca çalışmaların yayın dili bakımından, \%95.6'sı (n=366) İngilizce, \%1.8'i ( $\mathrm{n}=7$ ) İspanyolca, \% 0.5' $\mathrm{i}$ $(n=2)$ Türkçe, \%0.3'ü (n=1) Hirvatça, \%0.3’ü $(n=1)$ Flemenkçe, \%0.3'ü (n=1) Rusça, \%0.5’i (n=2) Fransızca ve \%0.8'inin ( $\mathrm{n}=3$ ) ise Almanca olduğu anlaşılmaktadır.

Bu çalışamaların 2000-2020 yılları arasındaki dağılımları Grafik 1'de gösterilmiştir.

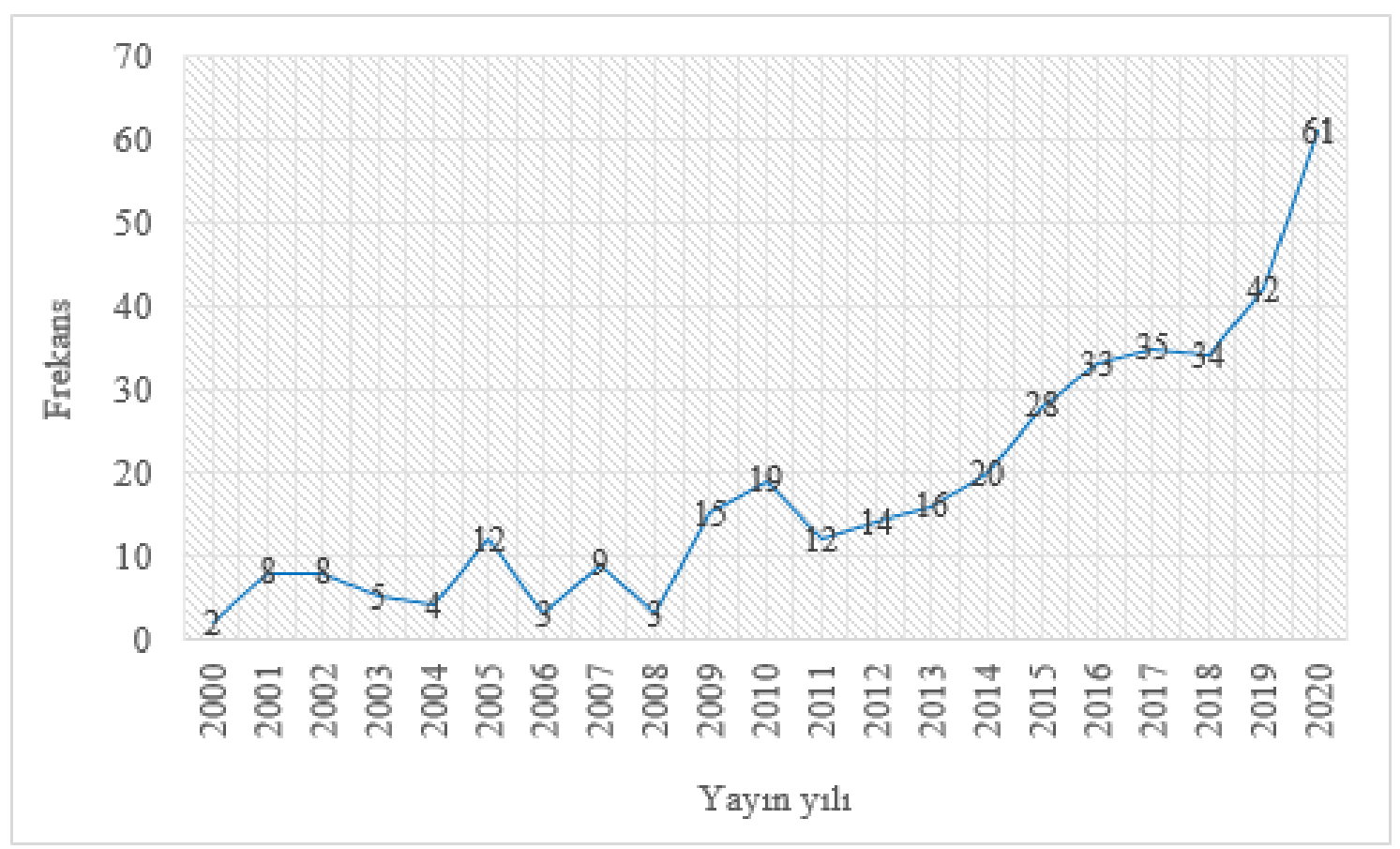

Grafik 1. Eğitimde aile katılımı yayınlarının yıllara göre dağılımı 
Grafik 1 incelendiğinde 2000-2020 yılları arasında aile katılımı konusundaki çalışmların belirli yıllarda azalış göstermekle birlikte, özellikle 2011 yılından itibaren tırmanışa geçtiği anlaşılmaktadır. Ayrıca aile katılımı yayınlarının, 2020 yılında zirveye ulaştığıda görülmektedir.

\section{Verilerin toplanması}

$\mathrm{Bu}$ çalışmanın amacı doğrultusunda, Web of Science (WoS) veri tabanından aile katılımı yayınları çekilmiştir. Bu işlemi yapmak için, ilk olarak WoS veri tabanı arama bölmesinde "ilgili terim" olarak "Parental Involvement" girilmiş, arama biçimi olarak ise "Title" seçilmiştir. İkinci olarak, "belge türü", "makale" kategorisi olarak belirlenmiştir. Üçüncü olarak "yayın yılı" sınırlandırılmış ve "2000-2020" aralığı girilmiştir. Ve son olarak, belgeler "eğitim araştırmaları", "aile çalışmaları" ve "psikoloji eğitimi" olarak veri tabınından özelleştirilerek çekilmiştir. Sonuç olarak aile katılımı ile ilgili toplam 383 yayın elde edilmiştir. Bu çalşımada, WoS veri tabanına tanımlanan ilgili terimler Şekil 1'de yer almaktadır.

\section{Results: 383}

(from Web of Science Core Collection)

You searched for: TITLE: ("Parental Involvement") AND YEAR PUBLISHED: (2000-

2020) AND DOCUMENT TYPES: (Article)

Refined by: WEB OF SCIENCE CATEGORIES: (EDUCATION EDUCATIONAL RESEARCH OR

FAMILY STUDIES OR PSYCHOLOGY EDUCATIONAL)

Timespan: All years. Indexes: SCI-EXPANDED, SSCI, A\&HCI, CPCI-S, CPCI-SSH, BKCI-S, BKCI-

SSH, ESCI

Şekil 1. Eğitimde aile katılımı konusundaki yayınları WoS veri tabanından çekmek için tanımlanan terimler

\section{Verilerin analizi}

$\mathrm{Bu}$ çalışmada, yayınların betimsel analizini yapmak için Excel programı, bibliyometrik haritaları oluşturmak için ise ücretsiz bir bilgisayar programı olan VOSviewer (bkz. Www.vosviewer.com) (van Eck ve Waltman, 2010; 2011) kullanılmıştır. VOSviewer, bibliyometrik harita ağları, iki merkez nokta arasındaki mesafeyi görselleştirmek için kullanışlı bir araçtır ve bu iki merkez noktanın ilişkisini gösterir (van Eck \& Waltman, 2014; van Eck, Waltman, Dekker, \& van den Berg, 2010). Verilerin analizi kapsamında WoS veri tabanından bilgisayara indirilen bibliyometrik verilerin ilk önce Excel programında düzenlemesi yapılmış ve ardından atıfların döküman, yazar, kaynak, kurum ve ülke bakımından betimsel analizleri yapılmıştır. Bu betimsel analizler, hem tablolar hemde grafikler yoluyla sunulmuştur. Yine aile katılımı konusundaki yayınların anahtar kelimler bakımından betimsel analizide yapılarak, tablo olarak gösterilmiştir. Çalışmamızda bibliyografik materyalin haritasını çıkarmak için VOSviewer yazılımı www.vosviewer.com adresinden ücretsiz olarak temin edilmiştir. Daha sonra VOSviewer programı kullanılarak 383 yayının ağ haritalaması yapılmıştır. Bir çalışma alanının tarihsel 
durumunu analiz etmek açısından atıf analizi önemli görülmektedir (Allahverdiyev \& Yucesoy, 2017). Bu bağlamda aile katılımı çalışmalarının "atıf (citation)" yapılarının, dokümanlar, kaynaklar, yazarlar, kurumlar ve ülkelere göre ağ haritası çıkarılmıştır. Ayrıca yayınların anahtar kelime ağ yapısıda VOSviewer programı kullanılarak haritalandırılmıştır. VoSviewer programında atıflara dayalı haritalama yapmak için girilen parametreler şu şekildedir:

- Bir dokümanın en az atıf sayısı 50 girildi, 383 çalışmadan 52'si bunu karşıladı.

- Bir kaynağın en az doküman sayısı 3 ve atıf sayısı 30 girildiğinde bunu 27 kaynak karşıladı.

- Bir yazarın minumum doküman sayısı 2, en az 20 atıf sayısı olması şartı arandığında bunu 38 yazar karşıladı.

- Bir kurumun en az doküman sayısı 3, en az atıf sayısı 30 girildiğinde bunu 37 kurum karşıladı.

- Bir ülkenin en az doküman sayısı 3, en az atıf sayısı 30 girildiğinde bunu 20 ülke karşıladı.

- Anahtar kelime oluşum sayısı 5 girildiğinde, 25'i bunu karşıladı.

\section{BULGULAR}

$\mathrm{Bu}$ bölüm, eğitimde aile katılımı konusundaki çalışmların, betimsel ve bibliyometrik analiz bulgularını içermektedir. Bu bulgular:

- En çok alıntı yapılan makalelerin yayın yılına göre dağılımını ve haritalanmasını içerir.

- En çok alıntı yapılan makalelerin dokümanlara, yazarlara, dergilere, kurumlara ve ülkelere göre dağılımını ve haritalanmasını içerir.

- Yayınlarda öne çıkan anahtar kelimeri ve bu anahtar kelimelerin ağ haritalamasını içerir.

Aile eğitimi konusundaki çalışmalarda en çok atıf alan ilk 20 çalışma Tablo 2'de gösterilmiştir.

Tablo 2. Eğitimde aile katılımı makalelerinde en fazla atıf alan 15 çalışmanın künyesi

\begin{tabular}{|c|c|c|c|c|c|}
\hline $\begin{array}{l}\text { Attf } \\
\text { Sayısı }\end{array}$ & Yazar/lar & Yıl & Yayın adı & Kaynak Adı & $\begin{array}{l}\text { Yayın } \\
\text { Dil }\end{array}$ \\
\hline 1035 & Fan, XT; Chen, M & 2001 & $\begin{array}{l}\text { Parental involvement and } \\
\text { students' academic } \\
\text { achievement: A meta-analysis }\end{array}$ & $\begin{array}{l}\text { Educational } \\
\text { Psychology Review }\end{array}$ & English \\
\hline 845 & $\begin{array}{l}\text { Senechal, M; } \\
\text { LeFevre, JA }\end{array}$ & 2002 & $\begin{array}{l}\text { Parental involvement in the } \\
\text { development of children's } \\
\text { reading skill: A five-year } \\
\text { longitudinal study }\end{array}$ & Ch1ld Development & English \\
\hline 553 & Jeynes, WH & 2007 & $\begin{array}{l}\text { The relationship between } \\
\text { parental involvement and urban } \\
\text { secondary school student } \\
\text { academic achievement- A } \\
\text { meta-analysis }\end{array}$ & Urban Education & English \\
\hline
\end{tabular}




\begin{tabular}{|c|c|c|c|c|c|}
\hline 516 & Jeynes, WH & 2005 & $\begin{array}{l}\text { A meta-analysis of the relation } \\
\text { of parental involvement to } \\
\text { urban elementary school } \\
\text { student academic achievement }\end{array}$ & Urban Education & English \\
\hline 322 & $\begin{array}{l}\text { Perna, LW; Titus, } \\
\text { MA }\end{array}$ & 2005 & $\begin{array}{l}\text { The relationship between } \\
\text { parental involvement as social } \\
\text { capital and college enrollment: } \\
\text { An examination of racial/ethnic } \\
\text { group differences }\end{array}$ & $\begin{array}{l}\text { Journal Of Higher } \\
\text { Education }\end{array}$ & English \\
\hline 309 & Jeynes, WH & 2003 & $\begin{array}{l}\text { A meta-analysis- The effects of } \\
\text { parental involvement on } \\
\text { minority children's academic } \\
\text { achievement }\end{array}$ & $\begin{array}{l}\text { Education And Urban } \\
\text { Society }\end{array}$ & English \\
\hline 291 & $\begin{array}{l}\text { Green, CL; } \\
\text { Walker, JMT; } \\
\text { Hoover-Dempsey, } \\
\text { KV; Sandler, HM }\end{array}$ & 2007 & $\begin{array}{l}\text { Parents' motivations for } \\
\text { involvement in children's } \\
\text { education: An empirical test of } \\
\text { a theoretical model of parental } \\
\text { involvement }\end{array}$ & $\begin{array}{l}\text { Journal Of Educational } \\
\text { Psychology }\end{array}$ & English \\
\hline 291 & $\begin{array}{l}\text { Hoover-Dempsey, } \\
\text { KV; Battiato, AC; } \\
\text { Walker, JMT; } \\
\text { Reed, RP; DeJong, } \\
\text { JM; Jones, KP }\end{array}$ & 2001 & $\begin{array}{l}\text { Parental involvement in } \\
\text { homework }\end{array}$ & $\begin{array}{l}\text { Educational } \\
\text { Psychologist }\end{array}$ & English \\
\hline 236 & $\begin{array}{l}\text { Englund, MM; } \\
\text { Luckner, AE; } \\
\text { Whaley, GJL; } \\
\text { Egeland, B }\end{array}$ & 2004 & $\begin{array}{l}\text { Children's achievement in early } \\
\text { elementary school: } \\
\text { Longitudinal effects of parental } \\
\text { involvement, expectations, and } \\
\text { quality of assistance }\end{array}$ & $\begin{array}{l}\text { Journal Of Educational } \\
\text { Psychology }\end{array}$ & English \\
\hline 233 & Wilder, S & 2014 & $\begin{array}{l}\text { Effects of parental involvement } \\
\text { on academic achievement: a } \\
\text { meta-synthesis }\end{array}$ & Educational Review & English \\
\hline 229 & $\begin{array}{l}\text { Gonzalez-DeHass, } \\
\text { AR; Willems, PA; } \\
\text { Holbein, MFD }\end{array}$ & 2005 & $\begin{array}{l}\text { Examining the relationship } \\
\text { between parental involvement } \\
\text { and student motivation }\end{array}$ & $\begin{array}{l}\text { Educational } \\
\text { Psychology Review }\end{array}$ & English \\
\hline 226 & $\begin{array}{l}\text { Hornby, G; } \\
\text { Lafaele, R }\end{array}$ & 2011 & $\begin{array}{l}\text { Barriers to parental } \\
\text { involvement in education: an } \\
\text { explanatory model }\end{array}$ & Educational Review & English \\
\hline 214 & Domina, $\mathrm{T}$ & 2005 & $\begin{array}{l}\text { Leveling the home advantage: } \\
\text { Assessing the effectiveness of } \\
\text { parental involvement in } \\
\text { elementary school }\end{array}$ & $\begin{array}{l}\text { Sociology Of } \\
\text { Education }\end{array}$ & English \\
\hline 212 & Jeynes, W & 2012 & $\begin{array}{l}\text { A Meta-Analysis of the } \\
\text { Efficacy of Different Types of } \\
\text { Parental Involvement Programs } \\
\text { for Urban Students }\end{array}$ & Urban Education & English \\
\hline 173 & Fan, XT & 2001 & $\begin{array}{l}\text { Parental involvement and } \\
\text { students' academic } \\
\text { achievement: A growth } \\
\text { modeling analysis }\end{array}$ & $\begin{array}{l}\text { Journal Of } \\
\text { Experimental } \\
\text { Education }\end{array}$ & English \\
\hline
\end{tabular}

Tablo 2'de WoS veri tabanında eğitimde aile katılımına ilişkin yapılan çalışmalar içerisinde en fazla atıf alan on beş çalışma yer almaktadır. Tablo 1 incelendiğinde 1035 atıfla en yüksek atıf sayısının 
2001 yılında Fan ve Chen, tarfından yapılan çalışma olduğu görülmektedir. Bu çalışmayı takiben 845 atıfla ikinci yüksek atıfın ise 2002 yılında Senechal, ve LeFevre tarafından yapılan çalışmaya ait olduğu anlaşılmaktadır. Ayrıca Jeynes, Hoover-Dempsey, Walker ve Fan gibi yazarların birden fazla çalışmalarınında yüksek atıf sayısına ulaştığıda görülmektedir.

Eğitimde aile katılımı konusunda yayınlanan çalışmalara ilişkin yapılan bibliyometrik analizler sonucunda atıfların, dökümanlara göre ağ haritası Şekil 2'de sunulmuştur.

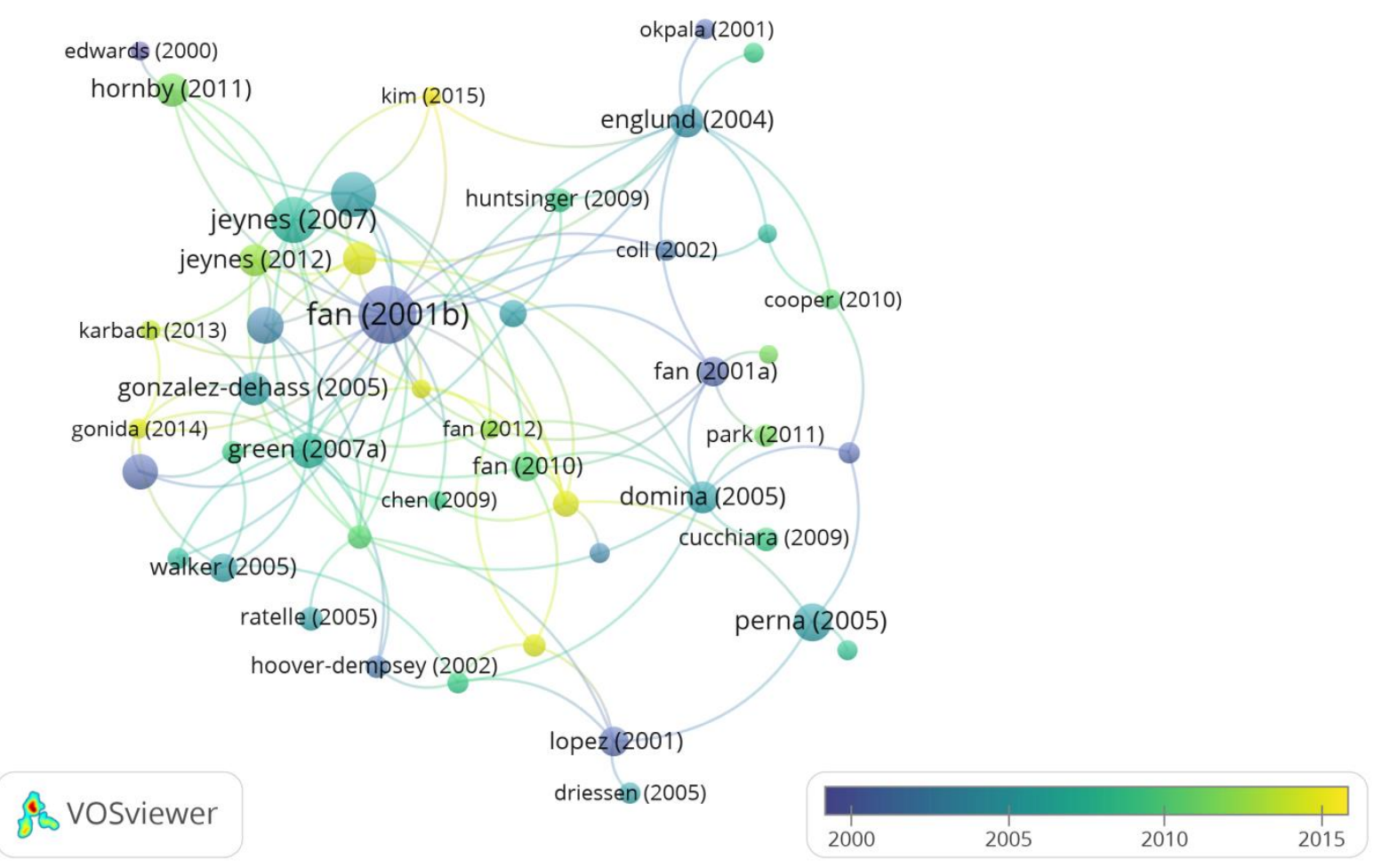

Şekil 2. Eğitimde aile katılmı konusunda atıfların dokümanlara dayalı ağ haritası

Şekil 2 eğitimde aile katılmı konusundaki atıfların dokümanlara göre ağ haritasını göstermektedir. $\mathrm{Bu}$ ağ haritası incelendiğinde, birçok renkte öne çıkan kümelenmelerin olduğu anlaşılmaktadır. Bu kümeler içinde bağlantı gücü en yüksek yazarların Fan (2001), Jeynes (2007) ve Green (2007) olduğu görülmektedir. Özellikle Fan (2001) diğer yazarları daha fazla besleyen bir yapıya sahip olduğu anlaşılmaktadır. Bu yazarın bağlantı gücünün daha fazla olması diğer yazarlara göre çok daha fazla atıf aldığınada işaret etmektedir.

Eğitimde aile katılmı konusunda yayın yapan dergilerin, toplam yayın sayıları ve ortalama atıf say1ları Grafik 2'de gösterilmiştir. 


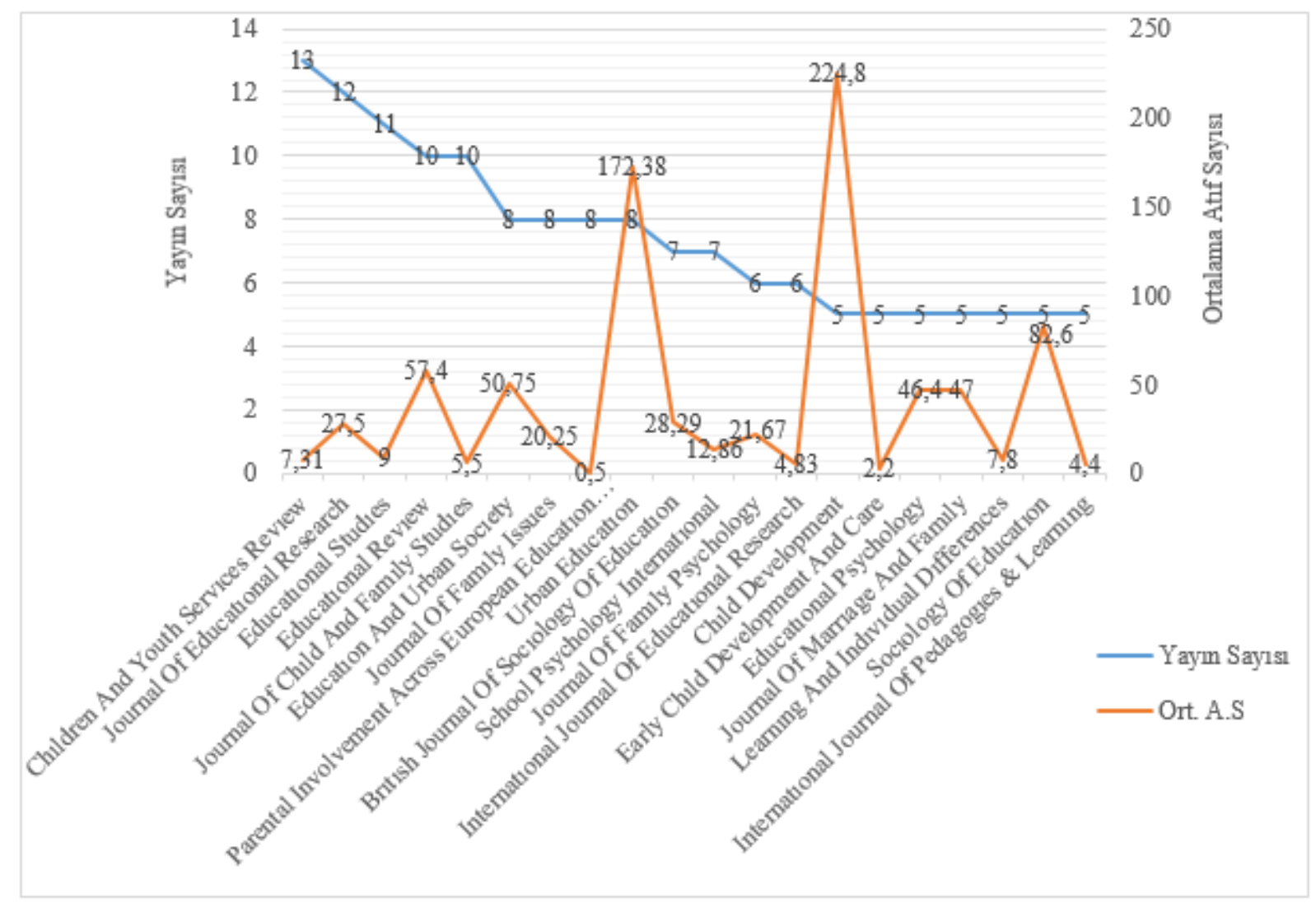

Grafik 2. Eğitimde aile katılmı konusunda en çok yayın yapan kaynakların yayın ve ortalama atıf sayısı

Grafik 2, eğitimde aile katılmı konusunda yayın yapan kaynakların, toplam yayın sayıları ve atıf ortalamalarını göstermektedir. Grafik incelendiğinde toplam 5 aile katılımı yayın sayısıyla 224.8 en yüksek atıf ortlamasına sahip kaynağın "Child Development" olduğu anlaşılmaktadır. Grafik incelendiğinde daha fazla yayın sayısına sahip birçok derginin ortalama atıf sayısının ise bu paralellikte bir artış göstermediği anlaşılmaktadır.

Eğitimde aile katılımı konusunda yayınlanan çalışmalara ilişkin yapılan bibliyometrik analizler sonucunda atıfların, kaynaklara göre ağ haritası Şekil 3'de sunulmuştur. 


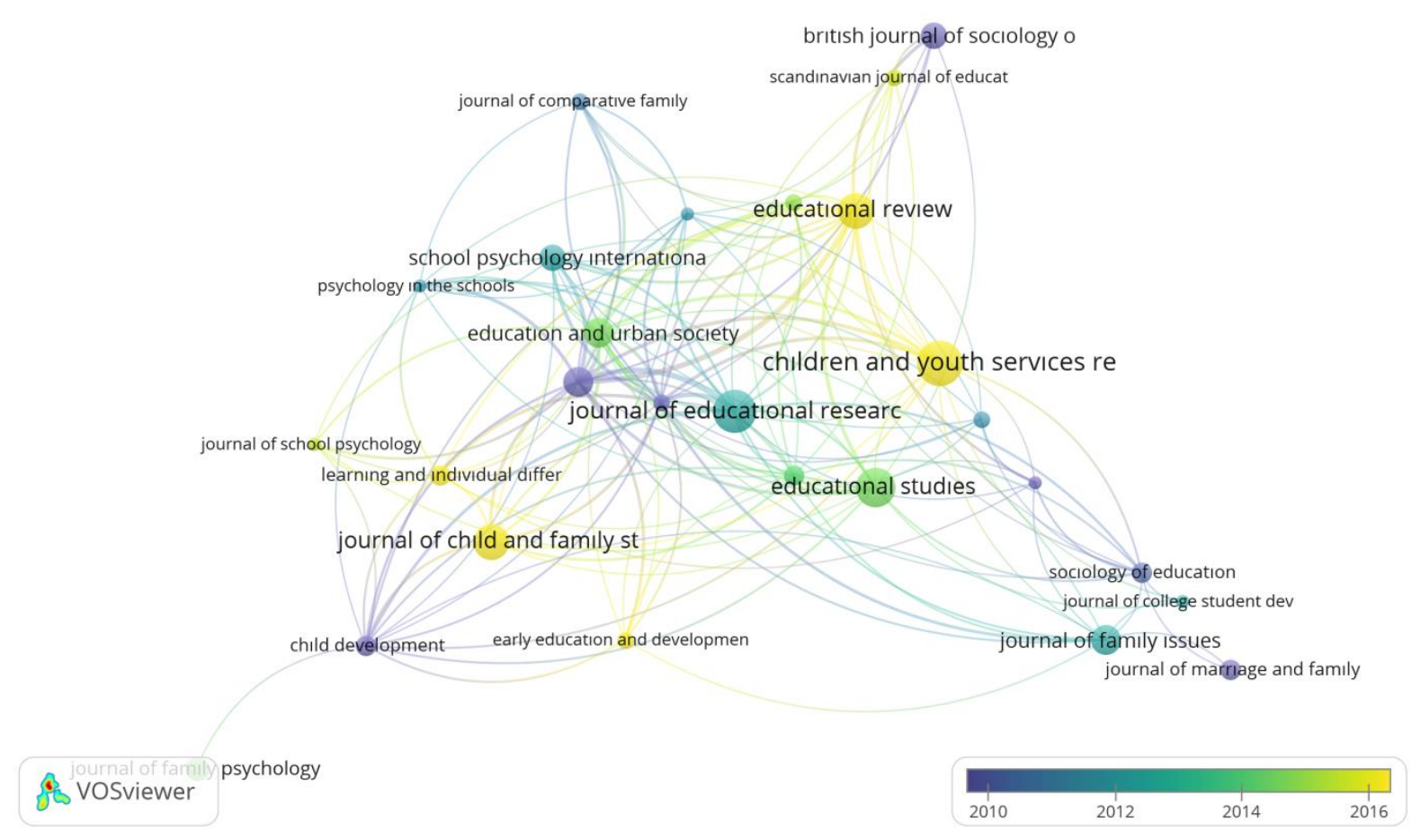

Şekil 3. Eğitimde aile katılmı konusunda atıfların kaynaklara dayalı ağ haritalaması

Şekil 3'te eğitimde aile katılmı konusunda atıfların yıllara göre kaynaklar bakımından ağ haritası gösterilmektedir. Bu ağ haritası incelendiğinde yıllara göre alıntı sayısı bakımından özellikle "Journal of Educational Research" ve "Children and Youth Services Review" dergilerinde yayınlanan çalışmların öne çıktığı anlaşılmaktadır. Özellikle bu kaynaklarda yayınlanan çalışmaların, diğer birçok kaynağ besleyen bir yapıya sahip olduğu anlaşılmaktadır. Bu kaynakların bağlantı gücünün daha fazla olması diğer kaynaklara göre çok daha fazla atıf aldığınada işaret etmektedir.

Eğitimde aile katılmı konusunda yayın yapan ülkelerin, toplam yayın sayıları ve ortalama atıf sayıları Grafik 3’te gösterilmiştir. 


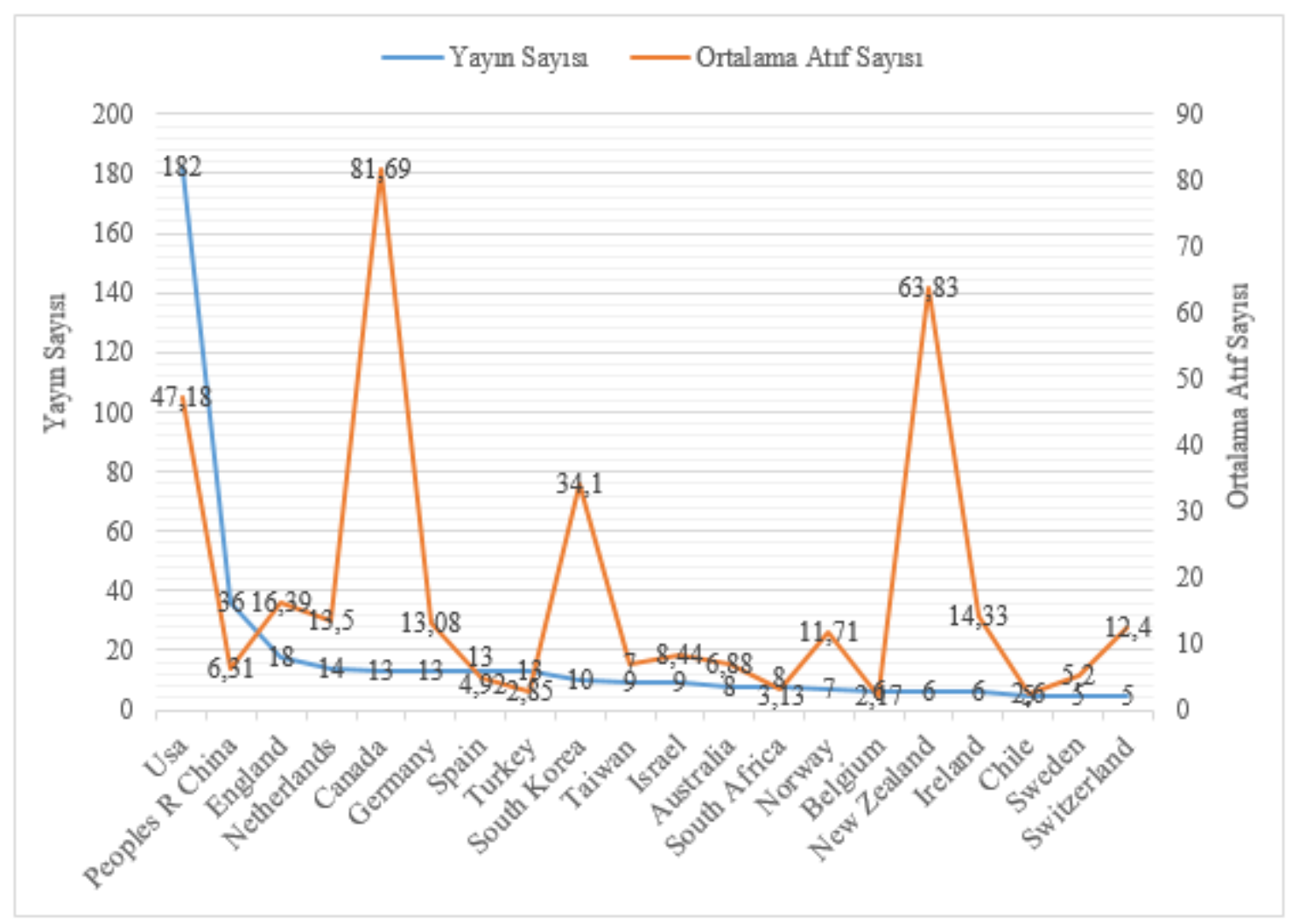

Grafik 3. Eğitimde aile katılmı konusunda en çok yayın yapan ülkelerin, yayın ve ortalama atıf sayısı dağılımı

Grafik 3, eğitimde aile katılmı konusunda yayın yapan ülkelerin, toplam yayın sayıları ve atıf ortalamalarını göstermektedir. Grafik incelendiğinde en yüksek atıf ortalamasına sahip ülkelerin, 13 aile katılımı yayını, 81.69 atıf ortlamasıyla "Kanada", ardından 6 yayın, 63.83'lük en yüksek ikinci atıf ortalamasıyla "Yeni Zellanda" olduğu anlaşılmaktadır. Grafik incelendiğinde bu konuda daha fazla yayın sayısına sahip birçok ülkenin, ortalama atıf sayısının bu paralellikte bir artış göstermediği anlaşılmaktadır.

Eğitimde aile katılımı konusunda yayınlanan çalışmalara ilişkin yapılan bibliyometrik analizler sonucunda atıfların, ülkelere göre ağ haritası Şekil 4'te sunulmuştur. 


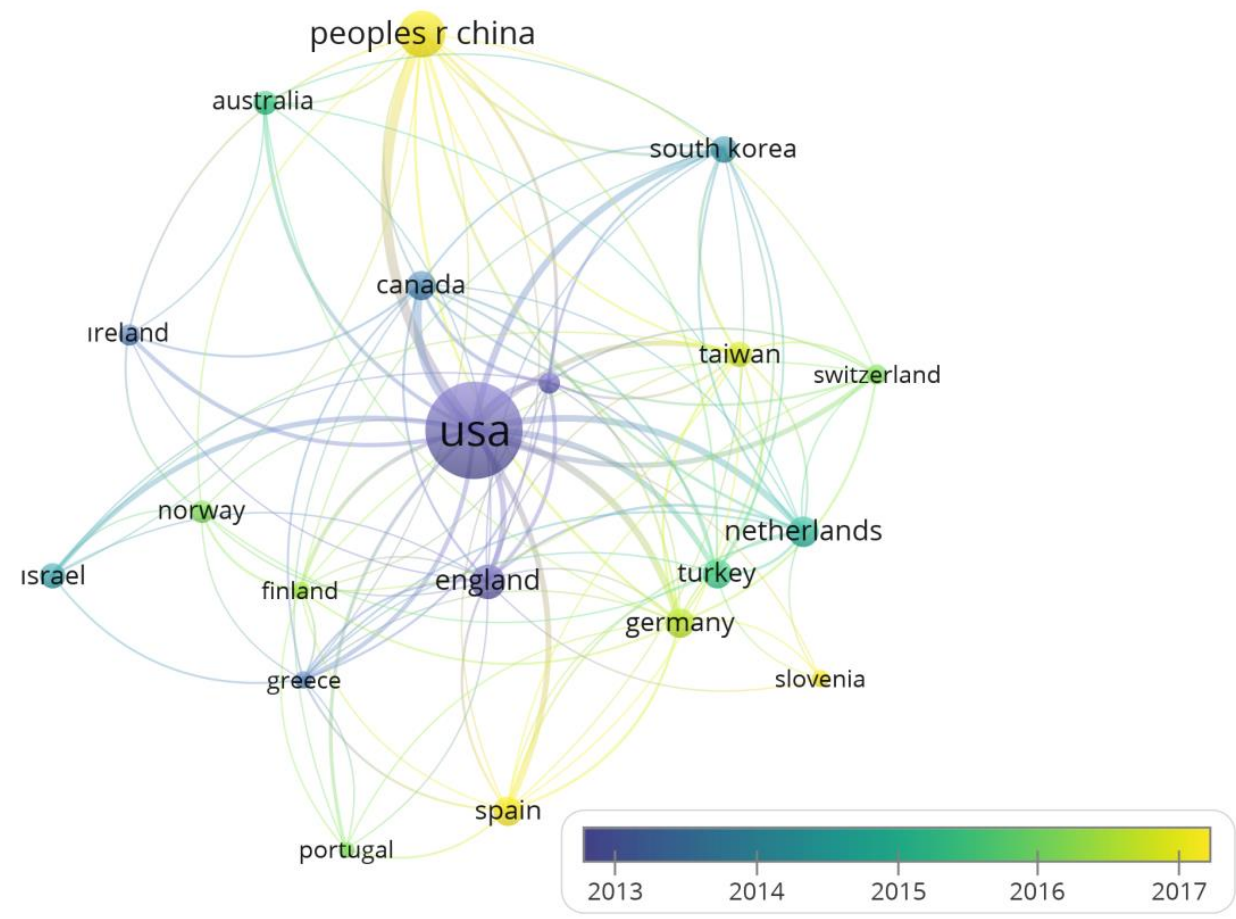

Şekil 4. Eğitimde aile katılmı konusunda atıfların ülkelere dayalı ağ haritalaması

Şekil 4, eğitimde aile katılmı konusundaki atıfların ülkelere göre ağ haritasını göstermektedir. $\mathrm{Bu}$ ağ haritası incelendiğinde eğitimde aile katılmı konusunda en çok katkı sağlayan ülkenin ABD olduğu anlaşılmaktadır. ABD'de yayınlanan çalışmaların, diğer birçok ülkede bu konuda yapılan çalışmaları besleyen bir yapıya sahip olduğu anlaşılmaktadır. Ayrıca, Çin, Tayvan ve İspanya kökenli yayınlarında son yıllarda bu alanı besleyen ülkeler olduğu görülmektedir.

Eğitimde aile katılmı konusunda yayın yapan kurumların, toplam yayın sayıları ve ortalama atıf sayıları Grafik 4’te gösterilmiştir. 


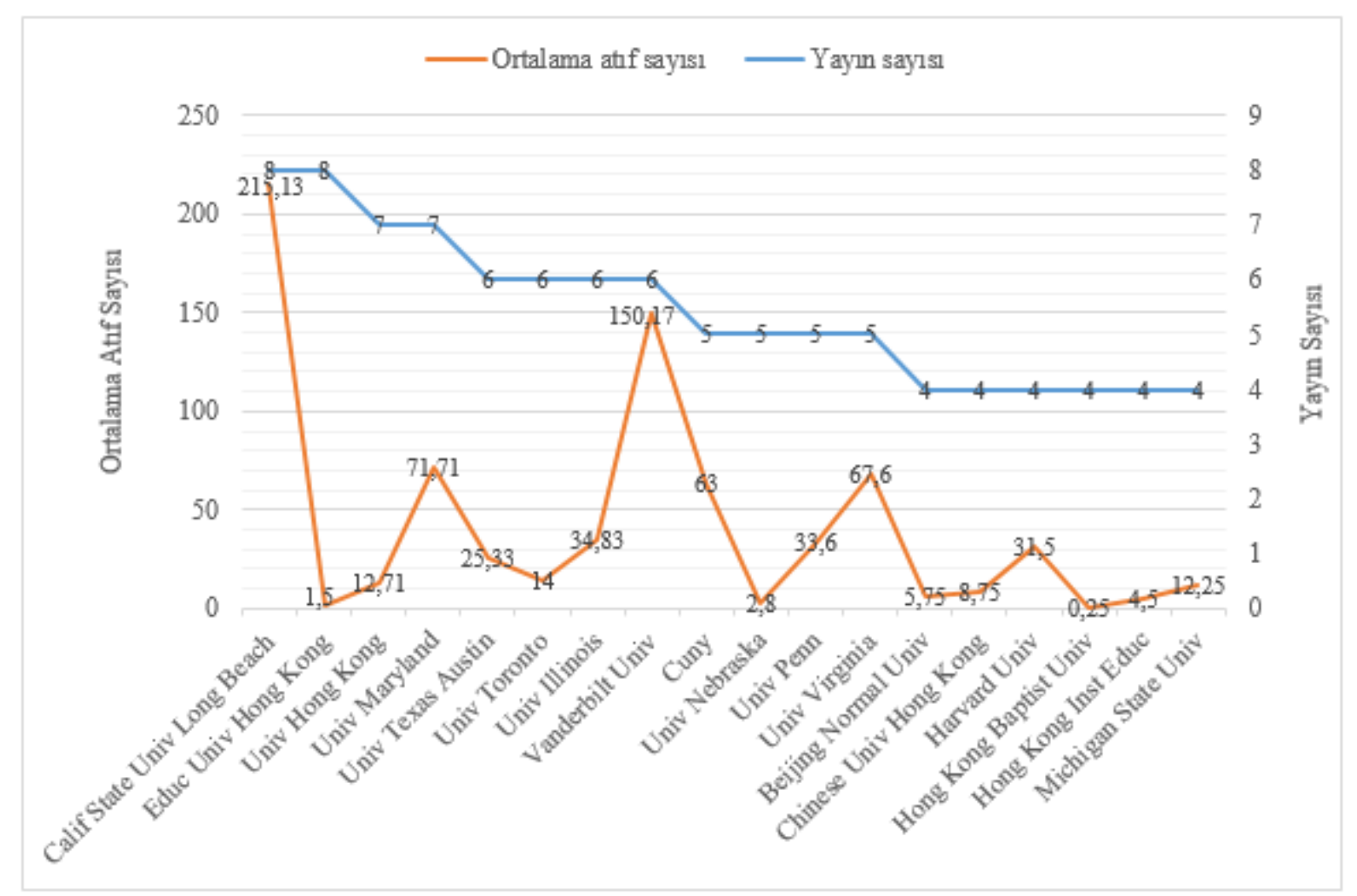

Grafik 4. Eğitimde aile katılmı konusunda en çok yayın yapan kurumların, yayın ve ortalama atıf sayısı

Grafik 4, eğitimde aile katılmı konusunda yayın yapan kurumların, toplam yayın sayıları ve atıf ortalamalarını göstermektedir. Grafik incelendiğinde en yüksek atıf ortalamsına sahip kurumların, 8 aile katılımı yayını, 215.13 atıf ortlamasıyla "Calif State University”, ardından 6 yayın, 150.17'lik en yüksek ikinci atıf ortalamasıyla "Vanderbilt University" olduğu anlaşılmaktadır. Grafik incelendiğinde bu konuda daha fazla yayın sayısına sahip birçok kurumun, ortalama atıf sayısının bu paralellikte bir artış göstermediği anlaşılmaktadır.

Eğitimde aile katılımı konusunda yayınlanan çalışmalara ilişkin yapılan bibliyometrik analizler sonucunda atıfların, kurumlara göre ağ haritası Şekil 5'te sunulmuştur. 


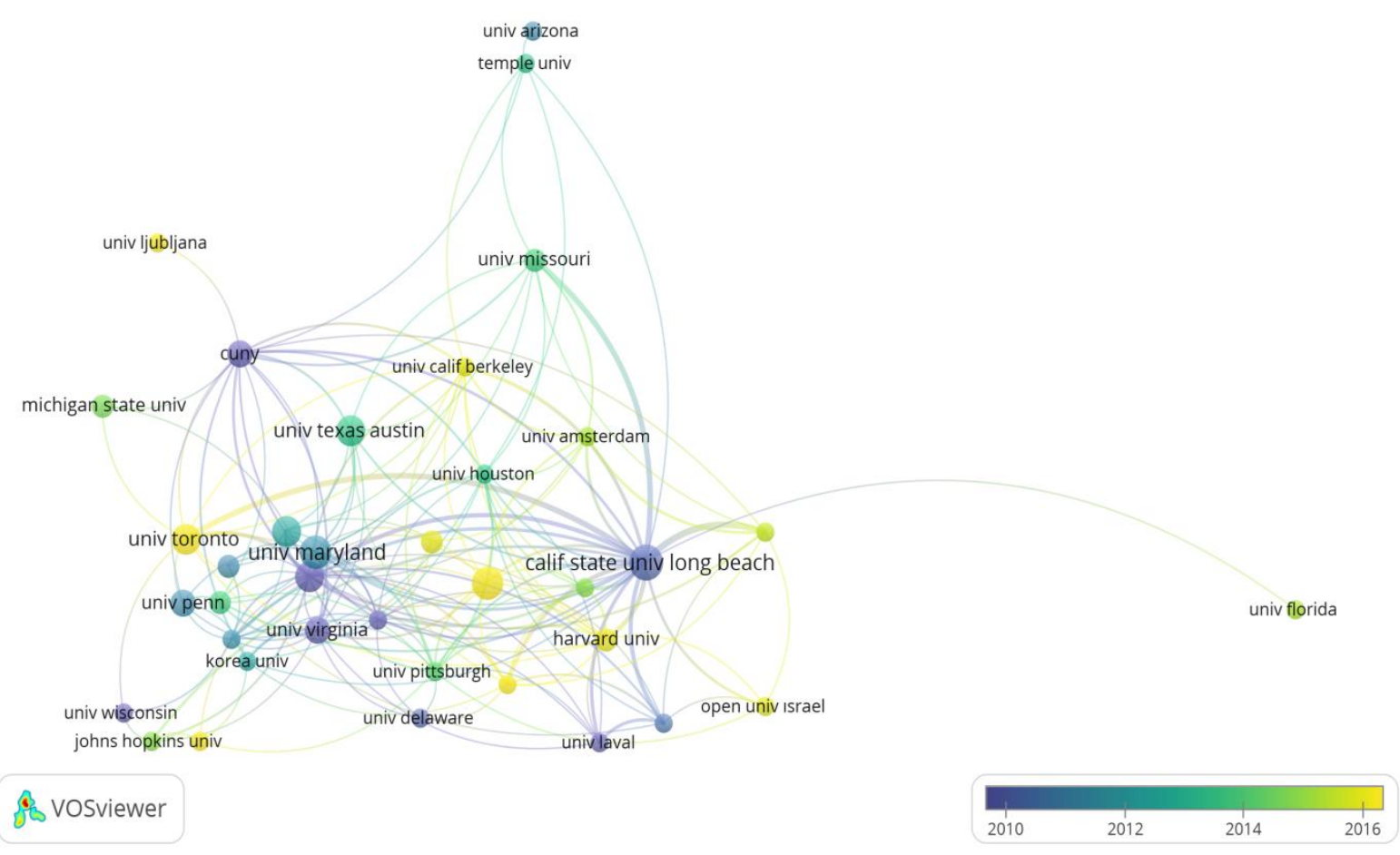

Şekil 5. Eğitimde aile katılmı konusunda atıfların kurumlara dayalı ağ haritalaması

Şekil 5, eğitimde aile katılmı konusundaki atıfların kurumlara göre ağ haritasını göstermektedir. $\mathrm{Bu}$ ağ haritası incelendiğinde eğitimde aile katılmı konusunda en çok katkı sağlayan kurumun "California State University" ve "The University of Maryland" olduğu anlaşllmaktadır. Bu kurumlardaki araştırmacıların çalışmalarının, diğer birçok kurumda bu konuda çalışan araştırmacıları besleyen bir yapıya sahip olduğu elde edilmiştir. Ayrıca, "The University of Toronto" son yıllarda bu alanı besleyen kurum olduğuda görülmektedir.

Eğitimde aile katılmı konusunda yayın yapan yazarların, toplam yayın sayıları ve ortalama atıf sayıları Grafik 5'te gösterilmiştir. 


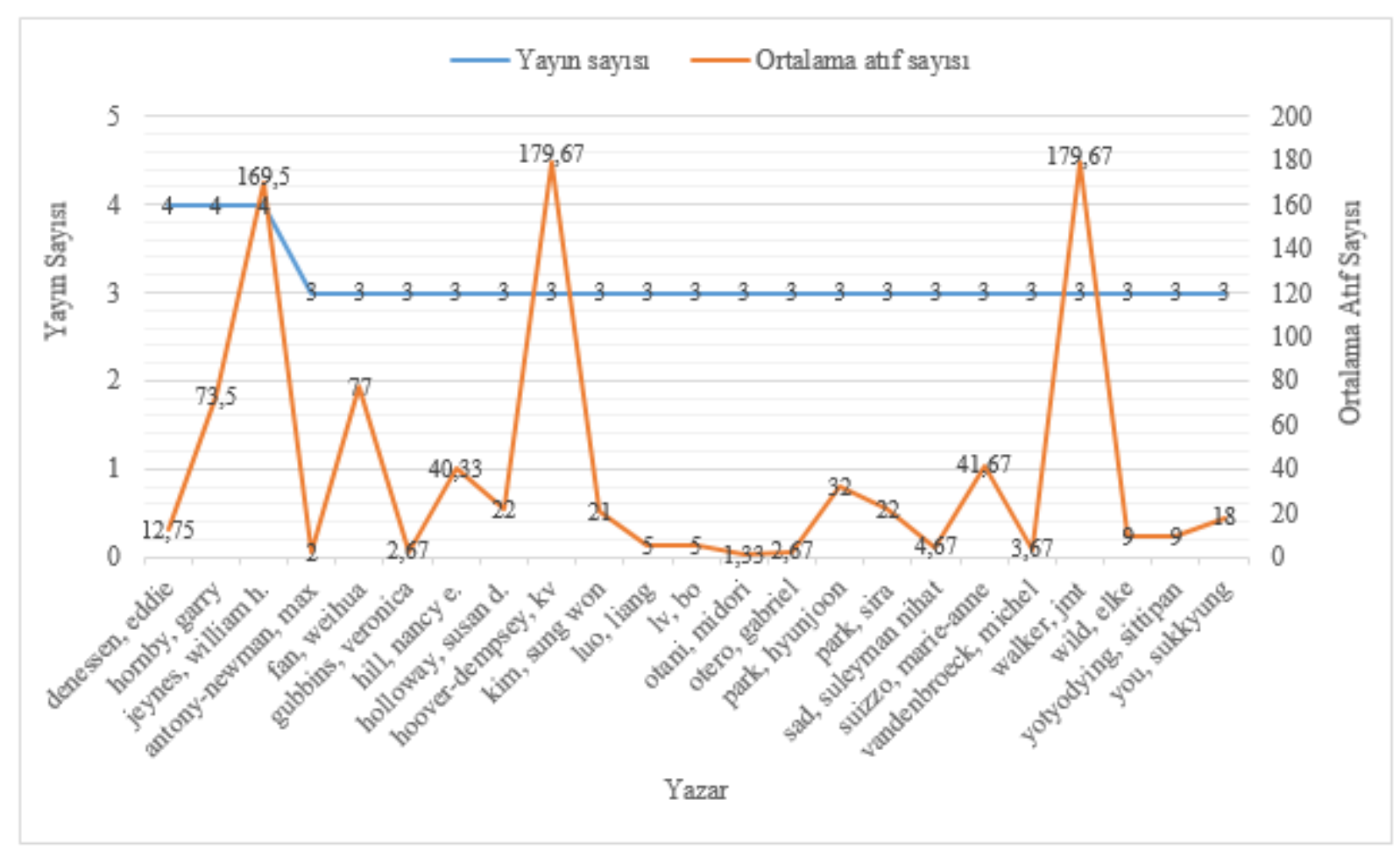

Grafik 5. Eğitimde aile katılmı konusunda en çok yayın yapan yazarların, yayın ve ortalama atıf sayısı

Grafik 5, eğitimde aile katılmı konusunda yayın yapan yazarların, toplam yayın sayıları ve atıf ortalamalarını göstermektedir. Grafik 5 incelendiğinde en yüksek atıf ortalamasına sahip yazarların, 3 'er aile katılımı yayını, 179.67 atıf ortlamasıyla "Hoover-Dempsey" ve "Walker" olduğu anlaşılmaktadır. Grafik incelendiğinde bu konuda eşit veya daha fazla yayın sayısına sahip birçok yazarın, ortalama atıf sayısının bu paralellikte bir artış göstermediği anlaşılmaktadır.

Eğitimde aile katılımı konusunda yayınlanan çalışmalara ilişkin yapılan bibliyometrik analizler sonucunda atıfların, yazarlara göre ağ haritası Şekil 6' da sunulmuştur. 


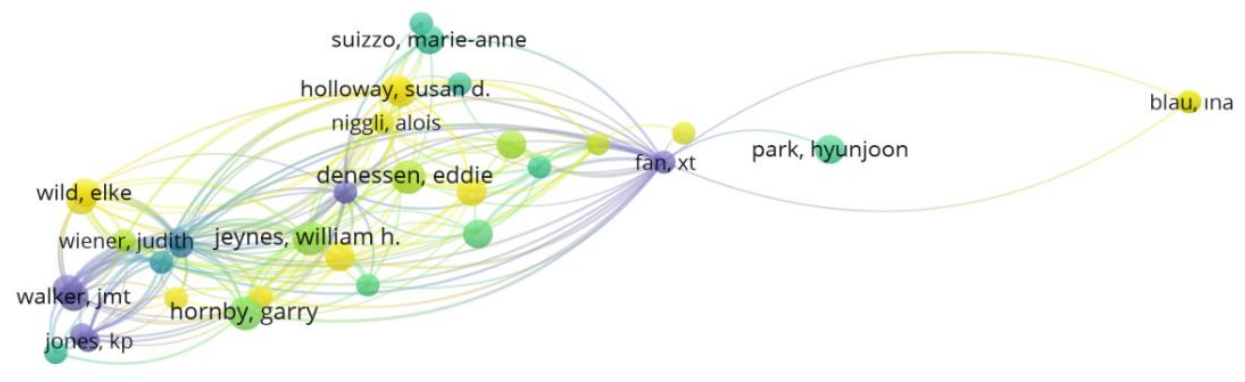

Vosviewer

$2006 \quad 2008 \quad 2010 \quad 2012 \quad 2014$

Şekil 6. Eğitimde aile katılmı konusunda atıfların yazarlara dayalı ağ haritalaması

Şekil 6, eğitimde aile katılmı konusundaki atıfların yazarlara göre ağ haritasını göstermektedir. $\mathrm{Bu}$ ağ haritası incelendiğinde eğitimde aile katılmı konusunda en çok katkı sağlayan yazarın "Fan", "Walker", "Jeynes" ve "Hornby" olduğu anlaşılmaktadır. Bu yazarların çalışmalarının, diğer birçok yazarı besleyen bir yapıya sahip olduğu görülmektedir. Ayrıca, "Wild" ve "Holloway"in son yıllarda bu alanı besleyen önemli yazarlar olduğuda anlaşılmaktadır.

Eğitimde aile katılmı konusundaki yayınların yıllara göre yazarlık bakımından anatomisi Tablo 3 'te yer almaktadır.

Tablo 3. Eğitimde aile katılımı konusunda yayınların yıllara göre anatomisi

\begin{tabular}{cccccc}
\hline Sira & Y11 & $\begin{array}{c}\text { Toplam } \\
\text { Yayın }\end{array}$ & $\begin{array}{c}\text { Tek yazarlı } \\
\text { Yayın }\end{array}$ & $\begin{array}{c}\text { Çok Yazarlı } \\
\text { Yayın }\end{array}$ & $\begin{array}{c}\text { Katk1 veren yazar } \\
\text { sayis1 }\end{array}$ \\
\hline 1 & 2020 & 61 & 16 & 45 & 159 \\
2 & 2019 & 42 & 11 & 31 & 100 \\
3 & 2018 & 34 & 6 & 28 & 92 \\
4 & 2017 & 35 & 7 & 28 & 83 \\
5 & 2016 & 33 & 5 & 28 & 94 \\
6 & 2015 & 28 & 5 & 23 & 81 \\
7 & 2014 & 20 & 4 & 16 & 48 \\
8 & 2013 & 16 & 5 & 11 & 46 \\
9 & 2012 & 14 & 7 & 7 & 23 \\
10 & 2011 & 12 & 6 & 6 & 21 \\
11 & 2010 & 19 & 9 & 10 & 42
\end{tabular}




\begin{tabular}{cccccc}
12 & 2009 & 15 & 4 & 11 & 35 \\
13 & 2008 & 3 & 1 & 2 & 6 \\
14 & 2007 & 9 & 2 & 7 & 23 \\
15 & 2006 & 3 & 1 & 2 & 5 \\
16 & 2005 & 12 & 4 & 8 & 34 \\
17 & 2004 & 4 & 2 & 2 & 8 \\
18 & 2003 & 5 & 1 & 4 & 11 \\
19 & 2002 & 8 & 1 & 7 & 23 \\
20 & 2001 & 8 & 2 & 6 & 21 \\
21 & 2000 & 2 & 0 & 2 & 5 \\
\hline
\end{tabular}

Tablo 3, eğitimde aile katılımı konusundaki yayınların y1llara göre yazarlık bakımından dağılımını göstermektedir. Tablo 3 incelendiğinde yazarlık bakımından, en çok tek yazarlı yayınların ( $f=16)$ ve çok yazarlı yayınların ( $f=45) 2020$ yılında üretildiği anlaşılmaktadır. Ayrıca 2018 ve öncesi yıllarda aile katılıma yönelik çalışmaların büyük oranda çok yazarlı olduğuda görülmektedir.

Eğitimde aile katılmı konusunda 2000-2020 yılları arasında yayınlanan çalışmların, toplam yayın ve atıf sayıları Grafik 6'da gösterilmiştir.

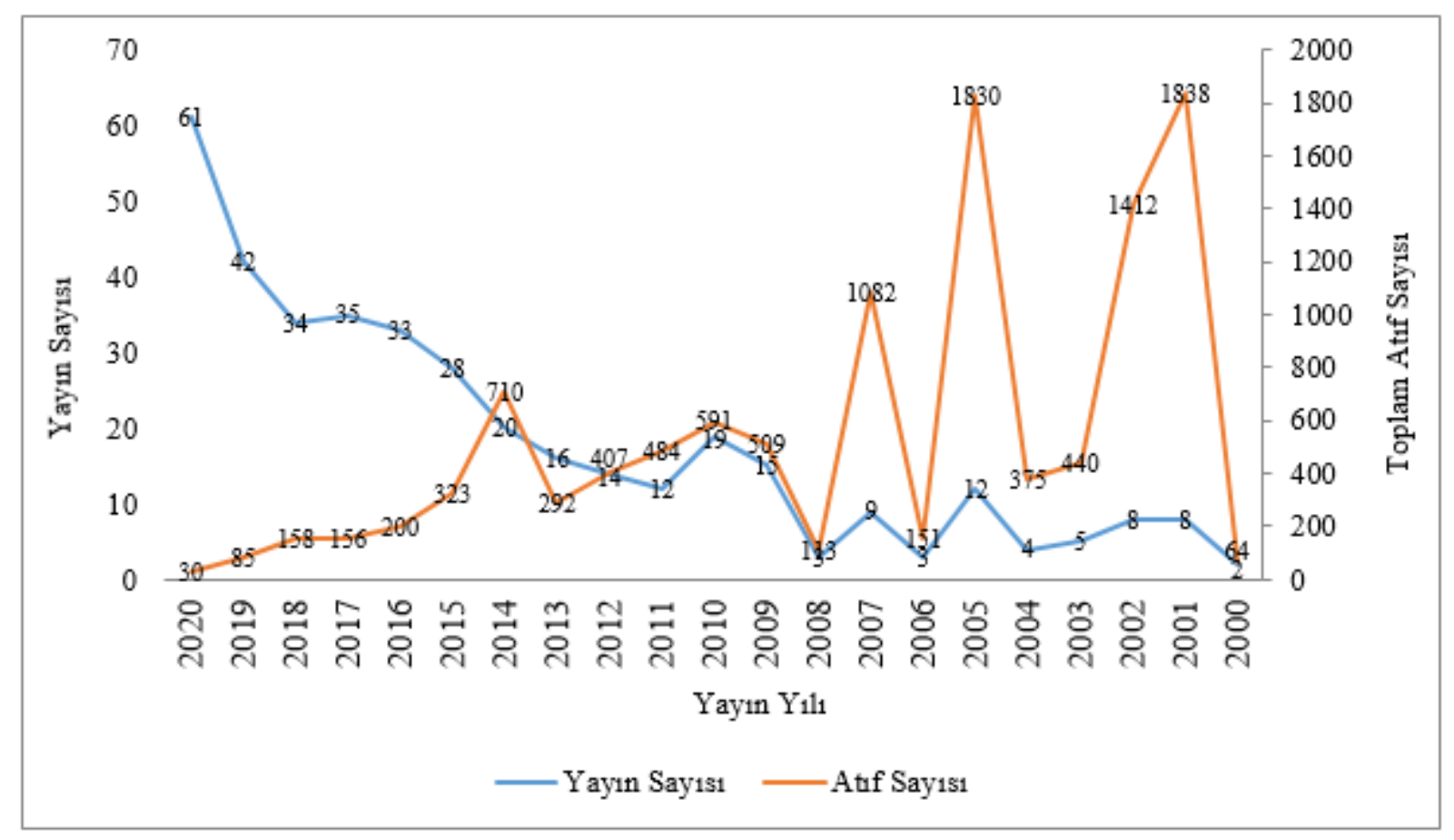

Grafik 6. Eğitimde aile katılımı konusunda yıllara göre yayın ve toplam atıf sayıları

Grafik 6, eğitimde aile katılmı konusunda 2000-2020 yılları arasında yayınlanan çalışmaların, toplam yayın ve atıf sayılarını göstermektedir. Grafik 6 incelendiğinde 1838 en yüksek atıf sayısına 64 yayınla 2000 yılında üretilen çalışmların ulaştığı anlaşılmaktadır. Bununla birlikte yine 1830 ikinci en 
yüksek atıf sayısına 12 yayınla 2005 yılındaki çalışmaların ulaştığı görülmüştür. Ayrıca son yıllarda yayın sayısının fazlalığına rağmen atıf sayısının zayıf kalmasıda grafikte yine öne çıkmaktadır.

Eğitimde aile katılmı konusundaki yayınınlarda en öne çıkan anahtar kelimeler Tablo 4’te yer almaktadır.

Tablo 4. Eğitimde aile katılımı konusundaki yayınınlarda en öne çıkan anahtar kelimeler

\begin{tabular}{llcc}
\hline Sira & Anahtar Kelimeler & Frekans (f) & Toplam bağlantı gücü \\
\hline 1 & parental involvement & 186 & 675 \\
2 & academic achievement & 26 & 97 \\
3 & education & 17 & 83 \\
4 & parent involvement & 16 & 58 \\
5 & parents & 12 & 51 \\
6 & achievement & 10 & 42 \\
7 & adolescents & 10 & 36 \\
8 & parenting & 10 & 41 \\
9 & homework & 8 & 31 \\
10 & adolescence & 7 & 28 \\
11 & elementary school & 7 & 31 \\
12 & mathematics & 6 & 28 \\
13 & meta-analysis & 6 & 25 \\
14 & schools & 6 & 17 \\
15 & structural equation modeling & 6 & 24 \\
\hline
\end{tabular}

Tablo 4'te eğitimde aile katılımı konusundaki yayınınlarda öne çıkan ilk 15 anahtar kelimenin frekans ve bağlantı gücü sayıları yer almaktadır. Tablo 4 incelendiğinde "parental involvement” un en fazla ortak kullanılan ve bağlantı gücü en yüksek anahtar kelime olduğu anlaşılmaktadır.

Eğitimde aile katılımı konusunda yayınlanan çalışmalara ilişkin yapılan bibliyometrik analiz sonucunda ortaya çıkan anahtar kelime ağ yapısı Şekil 7'de sunulmuştur. 


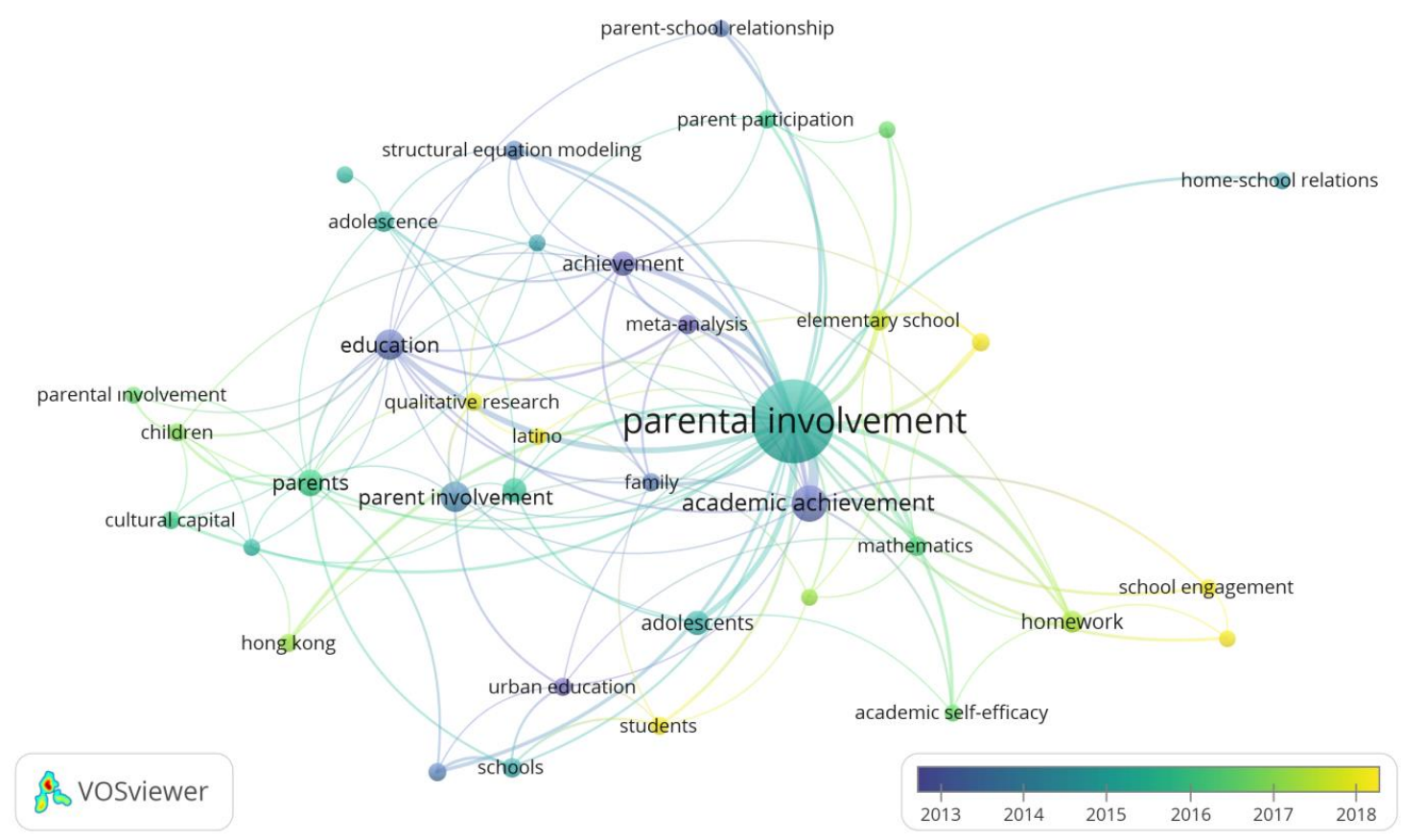

Şekil 7. Eğitimde aile katılımı konusunda anahtar kelime ağ haritası

Şekil 7'de, eğitimde aile katılımı konusunda ele alınan çalışmaların anahtar kelimeler ağ yapısı gösterilmektedir. Ağ haritası incelendiğinde eğitimde aile katılımı çalışmalarının merkezinde ve en yüksek besleyici özelliğe sahip anahtar kelimenin "parental involvement" olduğu anlaşılmaktadır. Ayrıca merkezilik bakımından önemli olan diğer anahtar kelimelerin ise "academic achievement", "parents", "parent involvement" ve "education” olduğu anlaşılmaktadır.

\section{TARTIŞMA ve SONUÇLAR}

$\mathrm{Bu}$ çalı̧̧ma, eğitimde aile katılımı üzerine 2000-2020 y1lları arasında yapılan yayınların nası1 şekillendiğini göstermektedir. Bu makalenin amacı, eğitimde aile katılımı konusundaki çalışmaların geçmişine genel bir bakış açısı sunmaktır. Çalışma, bu yıllar arasında üretilen aile eğitimi yayınlarının, yazarlar, kaynaklar, kurumlar ve ülkeler bakımından etkililiğine odaklanmıştır. Ayrıca anahtar kelimeler bağlamında öne çıkan temaların betimlenmesini ve haritalandırılmasını içermektedir. Bu çalışmanın sonuçları, aile katılımı yayınlarının, eğitim literatürünü nasıl şekillendirdiğini bize bildirmesi açısından dikkat çekicidir.

Yapılan analizler sonucunda aile katılımı yayınlarının, 2000-2020 yılları arasında bazı yıllarda düşüş yaşamakla birlikte 2011 yılından itibaren çıkışa geçtiği ve 2020 yılında zirve yaptığı saptanmıştır. Aile katılımı konusunda yapılan yayınların, atıf analizi sonucunda en çok atıf alan yazarların Xitao Fan ve Michael Chen, olduğu görülmüştür. Bu kapsamda, her iki araştırmacının yayınlarının diğer 
araştırmacıların yayınlarını güçlü bir şekilde beslediği söylenebilir. Aile katılımı konusunda, en fazla yayın sayısına sahip kaynağın "Children and Youth Services Review", en yüksek atıf ortalamasına sahip kaynağın ise "Child Development" olduğu bulunmuştur. Bu durum, "Child Development” kaynağının diğer kaynakları güçlü bir şekilde beslediği anlamına gelmektedir. Aile katılımı konusunda, en fazla yayın sayısına sahip kurumların "California State University" ve "The Education University of Hong Kong", en yüksek atıf ortalamasına sahip kurumun ise "California State University" olduğu görülmüştür. Bu bağlamda "California State University" kurumuna bağlı araştırmacıların aile katılımı konusunda üretmiş olduğu yayınların diğer yayınları güçlü bir şekilde beslediği söylenebilir. Aile katılımı konusunda, en fazla yayın sayısına sahip ülkenin ABD, en yüksek atıf ortalamasına sahip ülkenin ise Kanada olduğu saptanmıştır. Aile katılımı konusunda Kanada kökenli yayınların diğer ülkelerin üretmiş olduğu yayınlara kıyasla, bu alandaki yayınları beslemede daha güçlü bir etkiye sahip olduğu söylenebilir. Aile katılımı konusunda, en fazla yayın sayısına sahip yazarların Eddie Denessen, Garry Hornby ve William Jeynes, en yüksek atıf ortalamasına sahip yazarların ise Kathleen V. HooverDempsey ve Joan M. T. Walker, olduğu görülmüştür. Bu durum, aile katılımı konusundaki çalışmaları beslemeye ilişkin, Hoover-Dempsey ve Walker isimli yazarların daha güçlü bir etkiye sahip olduğu anlaşılmaktadır.

Eğitimde aile katılımına ilişkin yayınların anahtar kelimeler yapısı bakımından bibliyometrik analizi sonucunda çalışmaların merkezinde ve en yüksek frekansa sahip anahtar kelimenin "parental involvement" olduğu görülmüştür. Anahtar kelimeler, arama motorlarının ilgili yayınları bulmasına yardımcı olan bir araçtır (Springer, 2017). Bu analiz çerçevesinde, "parental involvement" anahtar kelimesinin, eğitimde aile katılımı çalışmalarında öne çıkması, disiplin alanlarının birçoğunda içeriği en belirgin ve en iyi tanımlayan kelime olmasıyla açıklanabilir.

Mevcut incelemenin sonuçları, gelecekte eğitimde aile katılımı konusunda etkili yayınlar oluşturmak için akademisyenlere tematik çıkarımlar sunmaktadır. Bu bibliyometrik analiz, aile katılımı konusunda etkili eserleri, yazarları, kurumları ve ülkeleri açıkça göstermektedir. Dahası bu tür bir analiz, aile katılımı konusundaki çalışmaların görünmez yönlerini aydınlatma çabası içermektedir. Bu çalışma özellikle, yeni araştırmacılara hangi aile katılmı çalışmalarından teorik çıkarımlar elde edilebelecğinin ipuçlarını vermektedir.

\section{Öneriler}

Bulgular, tek bir veri tabanı, WoS'a dayanmaktadır. Dolayısıyla aile katılımı konusunda daha fazla veri tabanını kapsayan bir araşatırmaya ihtiyaç vardır. Ayrıca bu alandaki tezlerin incelenmesi eksik kalan yönleri tamamlayacak ve bu alanın daha derinlemesine anlaşılmasını sağlayacaktır. Aile katılımı konusunda daha fazla yayın ve alıntı eğilimi analizleri, yeni araştırmacıların hangi temaya 
eğilecekleri konusunda karar verirken, araştırma noktalarının daha fazla farkına varmalarını sağlayacaktır.

\section{Sinırlılıklar}

Aile katılımına ilişkin çalışmaların bibliyometrik analiziyle, sadece alıntı yapısını belirleyebildik. Buna karşın bu konuda yapılan çalışmaların içeriğinin nasıl olduğu bilinmemektedir. Ayrıca, aile katılımı konusundaki bilimsel araştırmaların katkılarına ilişkin tam potansiyellerinin ortaya çıkması uzun zaman alabilir. Dolayısısyla burada etki gücü zayıf gözüken birçok çalışmanın tam potansiyelini ortaya çıkarmak için gelecekte başka analizlere ihtiyaç duyulmaktadır.

\section{Ek Beyan}

\section{Yazar katkı oranları}

- "Yazarlar çalışmaya eşit oranda katkı sağlamıştır"

\section{Araştırma ve yayın etiği ilkelerine uygun hareket edildiğine dair metin}

- "Makalenin tüm süreçlerinde JCRE'ın araştırma ve yayın etiği ilkelerine uygun olarak hareket edilmiştir."

\section{3. Çıkar çatışması bildirimi}

- Bu çalı̧̧mada herhangi bir potansiyel çıkar çatışması bulunmamaktadır.

\section{KAYNAKÇA}

Al-Mahdi, O. (2019). Family-school connections: Different theoretical perspectives and their implications for teacher education. Humanities and Social Science Research, 2(4), 13-21. doi:10.30560/hssr.v2n4p13.

Allahverdiyev, M. \& Yucesoy, Y. (2017). Development stages and types of glass art from past to present. Ponte, 73(4), 224-238.

Bjork, S., Offer, A., \& Söderberg, G. (2014). Time series citation data: The Nobel prize in economics. Scientometrics, 98(1), 185-196. doi:10.1007/s11192-013-0989-5.

Cook-Craig, P. G. (2010). Using social network theory to influence the development of state and local primary prevention capacity-building teams. Journal of Family Social Work, 13(4), 313-325. doi:10.1080/10522158.2010.492497.

Cridge, B. J. \& Cridge, A. G. (2015). Evaluating how universities engage school students with science: A model based on the analysis of the literature. Australian Universities' Review, 57(1), 34-44.

Epstein, J. L. (2010). School/family/community partnerships: Caring for the children we share. Phi Delta Kappan, 92(3), 81-96. doi:10.1177/003172171009200326.

Falagas, M. E., Karavasiou, A. I., \& Bliziotis, I. A (2006). A bibliometric analysis of global trends of research productivity in tropical medicine. Acta Trop, 99(3), 155-159.

Geesa, R. L., Izci, B., Song, H. S., \& Chen, S. (2019). Exploring the roles of students' home resources and attitudes towards science in science achievement: a comparison of South Korea, Turkey, and the 
United States in TIMSS 2015. Asia-Pacific Science Education, 5(17), 1-22. doi:10.1186/s41029-0190038-7.

Geng, S., Wang, Y., Zuo, J., Zhou, Z., Du, H., \& Mao, G. (2017). Building life cycle assessment research: A review by bibliometric analysis. Renewable and Sustainable Energy Reviews, 76, 176-184. doi: 10.1016/j.rser.2017.03.068.

Gimenez-Espert, M. D. C., \& Prado-Gasco, V. J. (2019). Bibliometric analysis of six nursing journals from the Web of Science, 2012-2017. Journal of Advanced Nursing, 75(3), 543-554. https://doi.org/10.1111/jan.13868

Gross, D., Bettencourt, A. F., Taylor, K. et al. (2020). What is parent engagement in early learning? Depends who you ask. Journal of Child and Family Studies, 29, 747-760. doi:10.1007/ s10826-019-01680-6.

Halim, L., Rahman, N. A., Zamri, R., \& Mohtar, L. (2018). The roles of parents in cultivating children's interest towards science learning and careers. Kasetsart Journal of Social Sciences, 39(2), 190-196. doi:10.1016/j.kjss.2017.05.001.

LaRocque, M., Kleiman, I., \& Darling, S. M. (2011). Parental involvement: The missing link in school achievement. Preventing School Failure, 55(3), 115-122. doi:10.1080/10459880903472876.

Levine, K. A., \& Sutherland, D. (2013). History repeats itself: Parental involvement in children's career exploration. Canadian Journal of Counselling \& Psychotherapy, 47(2), 239-255.

Malone, D. (2015). Culture: A potential challenge for parental involvement in schools. International Journal of Professional Educators, 82(1), 14-18.

Mart'inez MA, Cobo MJ, Herrera M, Herrera-Viedma E (2015) Analyzing the scientific evolution of social work using science mapping. Res Soc Work Pract, 5(2), 257-277. doi:10. 1177/1049731514522101

Nugent, G., Barker, B., Welch, G., Grandgenett, N., Wu, C., \& Nelson, C. (2015). A model of factors contributing to STEM learning and career orientation. International Journal of Science Education, 37(7), 1-22. doi:10.1080/09500693.2015.1017863.

Owen, K. B., Smith, J., Lubans, D. R., Ng, J. Y. Y., \& Lonsdale, C. (2014). Self-determined motivation and physical activity in children and adolescents: A systematic review and meta-analysis. Preventive Medicine, 67, 270-279. doi:10.1016/j.ypmed.2014.07.033.

Rice, L., Barth, J. M., Guadagno, R. E., Smith, G. P. A., \& McCallum, D. M. (2013). The role of social support in students' perceived abilities and attitudes toward math and science. Journal of Youth and Adolescence, 42, 1028-1040. doi:10.1007/s10964-012-9801-8.

Sawitri, D. R., Creed, P. A., \& Zimmer-Gembeck, M. J. (2014). Parental influences and adolescent career behaviours in a collectivist cultural setting. International Journal for Educational and Vocational Guidance, 14, 161-180. doi:10.1007/s10775-013-9247-x.

Schulze, S., \& Lemmer, E. (2016). The relationship between family experiences and motivation to learn science for different groups of grade 9 students in South Africa. African Journal of Research in Mathematics Science and Technology Education, 20(1), 15-24. doi:10.1080/10 288457.2015.1122897.

Schulze, S., \& Lemmer, E. (2017). Family experiences, the motivation for science learning and science achievement of different learner groups. South African Journal of Education, 37(1), 15-21. doi: 10.15700/saje.v37n1a1276. 
Silander, M., Grindal, T., Hupert, N., Garcia, E., Anderson, K., Vahey, P. \& Pasnik, S. (2018). What Parents Talk About When They Talk About Learning: A National Survey About Young Children and Science. New York, NY, \& Menlo Park, CA: Education Development Center, Inc., \& SRI International.

Stables, A., Noth, W., Olteanu, A., Pesce, S., \& Pikkarainen, E. (2018). Semiotic theory of learning: New perspectives in the philosophy of education. Routledge.

Tekin, A. (2011). Parent involvement revisited: Background, theories, and models. International Journal of Applied Educational Studies, 10(2), 1-13.

Van Eck, N., \& Waltman, L. (2010). Software survey: 'VOSviewer, a computer program for bibliometric mapping. Scientometrics, 84(2), 523-538.

Van Eck, N. J., \& Waltman, L. (2011). Text mining and visualization using VOSviewer. ISSI Newsletter, $7(3), 50-54$.

Van Eck, N. J., \& Waltman, L. (2014). Visualizing bibliometric networks. In Y. Ding, R. Rousseau, \& D. Wolfram (Eds.), Measuring scholarly impact: Methods and practice. Berlin: Springer.

Van Eck, N. J., Waltman, L., Dekker, R., \& van den Berg, J. (2010). A Comparison of two techniques for bibliometric mapping: multidimensional scaling and VOS. Journal of the American Society for Information Science and Technology, 61(12), 2405-2416.

Wanat, C. L. (2010). Challenges balancing collaboration and independence in homeschool relationships: Analysis of parents' perceptions in one district. School Community Journal, 20(1), 159-186.

Washington, L. V. (2016). The effects of parent involvement on student outcomes in a minority-serving charter high school (Unpublished doctoral dissertation). Walden University College of Education.

Windle, J. (2015). Making sense of school choice: politics, policies and practice under conditions of cultural diversity. New York: Palgrave, Macmillan.

Xu, J., Du, J., Wu, S., Ripple, H., \& Cosgriff, A. (2018). Reciprocal effects among parental homework support, effort, and achievement? An empirical investigation. Frontiers in Psychology, 9(2334), 1-11. doi:10.3389/fpsyg.2018.02334. 